\title{
In vitro analysis of antibacterial and antifungal potential of lichen species of Everniastrum of vexans, Parmotrema blanquetianum, Parmotrema reticulatum and Peltigera laciniata
}

\begin{abstract}
In vitro antibacterial and antifungal activity of the water, ethanol and dichloromethano extracts of four lichen species viz, Everniastrum cf. vexans, Parmotrema blanquetianun, Parmotrema reticulatum, Peltigera laciniata were proved against six bacteria strains (Staphylococcus aureus, Listeria monocytogenes, Proteus vulgaris, Escherichia coli, Pseudomonas aeruginosa and Klebsiella pneumonia) and six fungal yeasts (Candida albicans, C. glabrata, C. krusey, C. parapsilopsis, C. tropicalis, and Cryptococcus neoformans). Antimicrobial activity was analysed employing three methods of diffusion: the spot-on-a-lawn method, disk diffusion and well diffusion assay. Ethanol extracts of lichenized fungi were found more effective against tested yeast than dichloromethane extracts. Everniastrum $c f$. vexans showed the lowest MIC and MFC for both solvents.
\end{abstract}

Keywords: antimicrobial lichens, Everniastrum vexans, Parmotrema blanquetianun, Parmotrema reticulatum, Peltigera laciniata
Volume 2 Issue 3 - 2018

\author{
Claudia M Plaza,' Celina Pérez de Salazar,' \\ Ramón E Plaza,' Marietta Vizcaya, ${ }^{2}$ Gabriela \\ Rodríguez-Castillo, ${ }^{3}$ Gerardo Medina- \\ Ramírez ${ }^{1,4}$ \\ 'Faculty of Farmacia y Bioanálisis, University de los Andes, \\ Venezuela \\ ${ }^{2}$ Department of Organic Biomolecular Research Group, \\ University de los Andes, Venezuela \\ ${ }^{3}$ Department of Chemistry, National Experimental University \\ Francisco de Miranda,Venezuela \\ ${ }^{1,4}$ Faculty of Sciences, Polytechnic Higher School of Chimborazo,
} Ecuador

Correspondence: Claudia M Plaza, Faculty of Farmaciay Bioanálisis. University de los Andes, Venezuela,

Email claudiampz@gmail.com

Received: May 23, 2018 | Published: June 08, 2018

\section{Introduction}

Infectious diseases caused by bacteria, fungi and others microorganism remain a major threat to public health, despite tremendous progress in human medicine. Their impact is particularly great in developing countries because of the relative unavailability of medicines and the emergence of widespread drug resistance. Interests in natural products with antimicrobial properties have evolved as a result of current problems associated with the use of antibiotics. Plant derived antimicrobial compounds have been the source of novel therapeutics for many years. This may be due to the fact that these compounds show the structural intricacy and chemical diversity required to interact with antibacterial protein targets and provide vast opportunities for new drug development. ${ }^{1,2}$ Just as the higher plants have been used in folk medicine, lichens have also been used in food and in folk medicine in many countries over a considerable period of time. A lichen is a composite organism that emerges from algae or cyanobacteria (or both) living among filaments of fungus in a mutually beneficial (symbiotic) relationship. They represent taxonomically and physiologically a diverse group of organisms. Lichens produce a number of characteristic secondary metabolites called lichen substances, which seldom occur in other organisms. Depsides and depsidones are among the most common secondary metabolites produced by the fungal symbiont. The lichens and their metabolites are shown to possess various biological activities such as antimicrobial, antiviral, antiprotozoal, enzyme inhibitory, insecticidal, antitermite, cytotoxic, antioxidant, antiherbivore, wound healing, analgesic and anti-inflammatory. ${ }^{1-5}$ Lichens are very abundant organisms and can withstand hostile environmental conditions; therefore, they are able to colonize diverse ecosystems. It is estimated that there are between 17.500 and 20.000 species of lichens known in the world, with about 1.500 lichen-shaped fungi. ${ }^{6}$ In Venezuela, there are 1.320 species reported by and probably around an estimated 4.000 are expected to be discovered of which $85 \%$ are concentrated in the Venezuelan Andes, which represents one of the most rich and diverse regions of the world. Thus the aim of the present study was investigate the antibacterial and antifungal potential of four lichens from Venezuelan Andes i.e., Everniastrum cf. vexans, Parmotrema blanquetianun, Parmotrema reticulatum, Peltigera laciniata. ${ }^{7-9}$

\section{Materials and methods}

\section{Collection and identification of lichen samples}

The lichen specimens of Everniastrum cf. vexans Zahlbr. ex W.L. Culb. \& C.F. Culb, Parmotrema blanquetianum (Müll. Arg) Kalb, Parmotrema reticulatum (Taylor) M. \& Peltigera laciniata (G. Merr. ex Riddle) Gyeln, grows luxuriantly in the temperate regions of Mérida state (Venezuela), and was collected from different locations. The identification was performed morpho-anatomically using a stereomicroscope and optical microscope. For the identification, relevant keys and monographs were used and the selected samples were subsequently subjected to molecular phylogenetic analysis, which revealed that the material commonly identified as Everniastrum vexans represent undescribed specie (no published data). The voucher specimens were deposited at the herbarium MERF of the Facultad de Farmaciay Bioanálisis of the Universidad de Los Andes 
and in the Field Museum (F), with the number C1, C9, C4 and C5, respectively. ${ }^{10-13}$

\section{Chemicals}

Müller Hinton agar and broth (Difco ${ }^{\mathrm{TM}}$ ), Sabouraud dextrose agar $\left(\mathrm{BBL}^{\mathrm{TM}}\right)$, were purchased from Becton, Dickinson and Company (BD) USA, dimethyl sulfoxide (DMSO) was obtained of Sigma Chemicals, USA. Chloramphenicol and Fluconazole (Laboratorio Colmed International $\left.{ }^{\circledR}\right)$. All other routine chemicals used including the solvents were of analytical grade.

\section{Extraction from lichen sample}

Lichen samples were dried for a week in preparation for extraction. Three different solvent systems i.e. water, ethanol and dichloromethane were used to prepare the extracts. A sample amount of $10 \mathrm{~g}$ of each lichen were soaked separately with $250 \mathrm{~mL}$ of each solvent at room temperature. Aqueous extracts were obtained after being left overnight, while ethanol and dichloromethane extracts took seven days. All extracts were filtered using filter paper (Whatman No.1). Ethanol and dichloromethane extracts were concentrated removing the solvent through evaporation at room temperature.

\section{Microorganisms and media}

Six bacterial strains were used as test organisms in this study as follows: Staphylococcus aureus (ATCC 25923), Listeria monocytogenes (ATCC 19114), Escherichia coli (ATCC 25992), Pseudomonas aeruginosa (ATCC 27853), Klebsiella pneumoniae (ATCC 23357) and a clinical isolates Proteus vulgaris. All of the bacteria used were isolates of the collection maintained by the Biotechnology Laboratory of the Research Institute of Universidad de Los Andes. Also, the following six fungal yeasts were used as test organisms: Candida albicans ATCC 90028, C. glabrata ATCC 90030, C. krusei ATCC 6258, C. tropicalis ATCC 50628, C. parapsilosis ATCC 22019 and Cryptococcus neoformans as clinical isolate. These were obtained from the mycological collection maintained by the Mycological Laboratory Dr. Corrado Capretti at the Department of Microbiology, Universidad de Los Andes, Venezuela. Bacterial cultures were maintained on Mueller-Hinton agar substrates. Yeasts cultures were maintained on Sabouraud dextrose agar and were transferred to Müller-Hinton agar. All cultures were stored at $4^{\circ} \mathrm{C}$ and sub cultured every $24 \mathrm{hrs}$ for bacteria, $48 \mathrm{hrs}$ for Candida yeasts and $72 \mathrm{hrs}$ for Cryptoccocus.

\section{Test substances}

The lichen extracts were dissolved in dimethyl sulfoxide (DMSO); except the aqueous extract. The antibiotic Chloramphenicol $(30 \mu \mathrm{g})$ and the antimycotic fluconazole $(25 \mu \mathrm{g} / \mathrm{disc})$ were dissolved in sterile distilled water and used as positive controls and DMSO as negative control.

\section{Determination in vitro of antimicrobial activity}

The antimicrobial activity of extracts obtained from Everniastrum cf vexans, Parmotrema blanquetianum, P. reticulatum and Peltigera laciniata evaluated against test bacteria and yeasts were determined employing three methods of diffusion: the spot-on-a-lawn method, disk diffusion and well diffusion method. In the methods of diffusion was used an aliquot of $1 \mathrm{~mL}$ of fresh culture of the bacteria or yeast and inoculated in $15 \mathrm{~mL}$ on Müller Hinton agar. All experiments were carried out in triplicate for calculation of standard deviations. The sensitivity of microorganisms to extracts of the lichens examined was tested by determining the minimal inhibitory concentration (MIC) of bacterium and yeast. Also, the minimum bactericidal concentration (MBC) and minimum fungicidal concentration (MFC).

\section{Suspension preparation}

The microorganism suspensions were prepared by the direct colony method. The colonies were taken directly from fresh cultures of the plate and were rinsed with sterile distilled water, used to determine turbidity spectrophotometrically at $560 \mathrm{~nm}$ (for bacterias) and $530 \mathrm{~nm}$ (for yeast), and then further diluted to approximately $10^{8} \mathrm{CFU} / \mathrm{mL}$ for bacterias and $10^{6} \mathrm{CFU} / \mathrm{mL}$ for yeast, according to the procedure recommended by NCCLS (2002), adjusting to the turbidity of the 0.5 McFarland's standard in both case.

\section{Spot-on-a-lawn method}

The protocol used, was estimated using the method described. ${ }^{14}$ A quantity of $5 \mu \mathrm{L}$ of each extracts to $20 \mathrm{mg} / \mathrm{mL}$ and $100 \mathrm{mg} / \mathrm{mL}$ were spotted onto this lawn and after the plates were incubated for $24 \mathrm{hrs}$ (bacterias) and $48-72 \mathrm{hrs}$ (yeast) at $37^{\circ} \mathrm{C}$. After the incubation period, the inhibition zones were measured. The controls chloramphenicol, fluconazole and DMSO were used in the same way Figure 1.
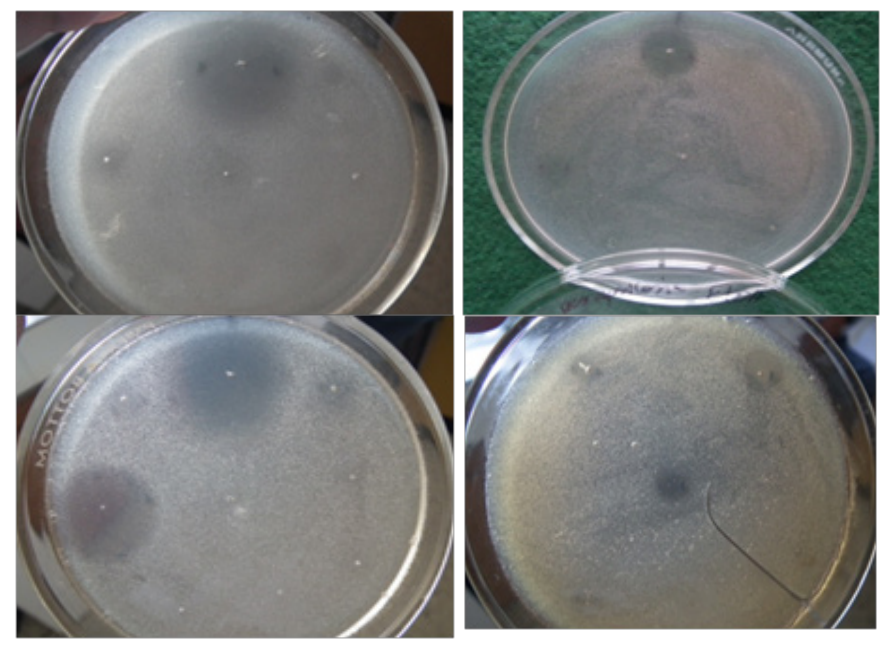

Figure ISpot-on-a-lawn method.

\section{Disc diffusion method}

The methodology was carried out according to Kirby-Bauer as described with slight modifications. Sterile filter paper discs (Whatman №1) $6 \mathrm{~mm}$ in diameter were impregnated with $5 \mu \mathrm{L}$ and $15 \mu \mathrm{L}$ of each extract at $100 \mathrm{mg} / \mathrm{mL}$ and $20 \mathrm{mg} / \mathrm{mL}$, respectively..$^{15}$ Also, individual disks soaked with $5 \mu \mathrm{L}$ and $15 \mu \mathrm{L}$ of chloramphenicol, fluconazole as positive control and DMSO as negative control were placed on plates previously inoculated and incubated at $37^{\circ} \mathrm{C}$ for $24-48 \mathrm{hrs}$ and $72 \mathrm{hrs}$. The inhibition zone was measured.

\section{Well diffusion method}

This method was used as described. In it, the agar was perforated using a sterile cork borer, wells of $3 \mathrm{~mm}$ and $6 \mathrm{~mm}$ diameter were made in the inoculated medium and then were filled with $5 \mu \mathrm{L}$ and $15 \mu \mathrm{L}$ extracts at $100 \mathrm{mg} / \mathrm{mL}$ and $20 \mathrm{mg} / \mathrm{mL}$, respectively. ${ }^{16}$ The same protocol was used with the chloramphenicol, fluconazole and DMSO as positive and negative controls. The plates were allowed to stand for 30 minutes and then, were incubated at $37^{\circ} \mathrm{C}$ for 24,48 and $72 \mathrm{hrs}$. The inhibition zone was recorded Figure 2. 

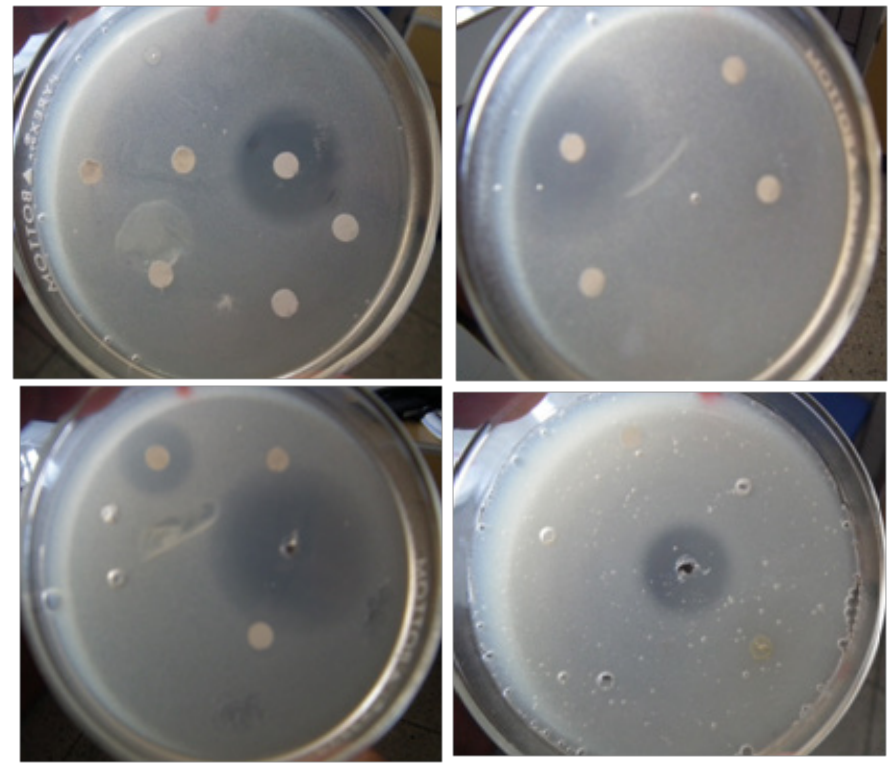

Figure 2 Disc diffusion and Well diffusion.

\section{Determination of minimum inhibitory concentration}

The MIC of the extracts was tested using the micro dilution method described. The MIC was determined in the samples that showed activity with any of the diffusion techniques. This was done in 96-well plates with "V" bottoms, which were prepared by dispensing $100 \mu \mathrm{L}$ in Müller Hinton broth into each well. A $100 \mu \mathrm{L}$ from a stock solution $200 \mathrm{mg} / \mathrm{mL}$ of each extract was added into the first column of the plate. Then, twofold serial dilutions were performed between the first and tenth column. Finally, $10 \mu \mathrm{L}$ of the diluted yeast suspension was added to each well to give a final concentration of $5 \times 10^{8} \mathrm{CFU} / \mathrm{mL}$ (for bacterias) and $5 \times 10^{6} \mathrm{CFU} / \mathrm{mL}$ (for yeast), making a final volume of $210 \mu \mathrm{L}$ in each well. The obtained concentration range was from 0.186 to $95.23 \mathrm{mg} / \mathrm{mL}$. Each test included growth control and sterility control. The chloramphenicol as positive control was evaluated between 512 to $1 \mu \mathrm{g} / \mathrm{mL}$ and the fluconazol between 0.125 to $64 \mu \mathrm{g} /$ $\mathrm{mL} \cdot{ }^{17,18}$ The DMSO was performed to study the effect on the growth of microorganism. The inoculated plates were incubated at $37^{\circ} \mathrm{C}$ for $24 \mathrm{hrs}$ and $48-72 \mathrm{hrs}$. After the incubation period, the plate was observed using a mirror. The lowest concentration of the extract that produced no visible growth (no turbidity) was regarded as MIC. ${ }^{19}$ All tests were performed in duplicate.

\section{Determination minimum bactericidal concentration and minimum fungicidal concentration}

The MBC and MFC were determined by plating $10 \mu \mathrm{L}$ of samples from each well where no visible growth was recorded, on the Müller Hinton agar (for the bacterias) and the Sauboraud Dextrosa agar medium (for the yeast). The plates were incubated at $37^{\circ} \mathrm{C}$ for $24 \mathrm{hrs}$ (bacteria) and 48-72hrs (yeast). At the end of the incubation period the lowest concentration with no growth, was defined as MBC or MFC. The MBC/ MFC were the minimum concentrations of the compound or drug that could inhibit $100 \%$ microbial growth..$^{20,21}$

\section{Statistical analysis}

The data were expressed as the means $(\overline{\mathrm{X}}) \pm$ standard deviation
(SD). All statistical analysis was performed using SPSS package (SPSS for Windows ver. 15, Chicago, IL, USA). Mean differences were established by Student's t-test. Data were analyzed using oneway analysis of variance (ANOVA). In all cases, $p$ values $<0.05$ were considered statistically significant.

\section{Result and discussion}

\section{In vitro Assays: Spot-on-a-lawn method, disc diffusion and well diffusion}

The report of the antibacterial and antifungal activity, using agar diffusion techniques for the ethanolic and dichloromethane extracts of the lichen species studied, were recorded as inhibition zone in $\mathrm{mm}$ against six bacterial species and six yeasts. Aqueous extracts didn't manifest any activity in relation to the microorganisms tested. Some literature data reported that aqueous extracts of lichens have no antimicrobial effects. ${ }^{22,23}$ The results obtained in the antibacterial activity of ethanol and dichloromethane extracts at $100 \mathrm{mg} / \mathrm{mL}$ of all lichen species studied are shown in Table 1. The four lichens Everniastrum cf. vexans, Parmotrema blanchetianum, Parmotrema reticulatum and Peltigera laciniata were active only against Proteus vulgaris except ethanol extracts of Parmotrema reticulatum that was also active against Staphylococcus aureus Figure 3. All results were corroborated by the techniques: spot-on-a-lawn method and well diffusion technique. No inhibition was reported by the disk diffusion technique. The standard chloramphenicol presented activity in almost all bacterial strains tested, except Listeria monocytogenes and Escherichia coli, being the persistent results in the three techniques use Previous research had reported antibacterial activity in several lichen species against Gram-positive and Gram negative bacterias in a wide variety of concentrations, under some technique used. ${ }^{24-27}$ Some authors indicate that the vast majority of lichens are more active against Gram-positive than Gram-negative bacteria. ${ }^{5,23}$ The difference in sensitivity between bacterias can be attributed to the different composition of the cell walls that exists between these microorganisms (varying permeability), which in some cases blocks the entry of certain compounds into the cellular interior. Grampositive bacteria are composed of peptidoglycan (murein) and teicoic acid, while Gram-negative bacteria possess lipopolysaccharides and lipoproteins, making them more resistant to certain antibiotics. ${ }^{23,28,29}$ However, the results in our finding are not consistent with previous studies on the antibacterial action of lichens, because both extracts were only active against a gram positive bacterium (Proteus vulgaris) and Staphylococcus aureus that resulted sensitive to Parmotrema reticulatum Table 1 . It can be attributed to the small amount $(5 \mu \mathrm{L})$ of the sample used and its high concentration $(100 \mathrm{mg} / \mathrm{mL})$ tested, which affected the diffusion of the sample in the medium.

EtOH: ethanol extracts. DCM: dichloromethane extracts. Sign Sign: without activity. Ev, Everniastrum cf. vexans; $P b$, Parmotrema blanchetianum; Pr, Parmotrema reticulatum; Pl, Peltigera laciniata. ${ }^{*} p<0.05$ represents the statistical difference between the three diffusion methods and between the four lichens used. In the Table 2 shows the results of antifungal activity of ethanol and dichloromethane extracts of the four lichens studied by the three diffusion methods. The ethanol extracts showed a range of inhibition zone between $5.6 \pm 1.5$ and $9.3 \pm 0.5 \mathrm{~mm}$. Everniastrum $\mathrm{cf}$ vexans, exhibiting effects different by the different techniques. For example, in the spot-on-a-lawn method evaluated at the lower concentration, it only showed inhibition zone against Candida tropicalis, whereas the disk and well technique at the 
same concentration were actives against C. parapsilosis, C. tropicalis and Cryptococcus neoformans. However, at a higher concentration, were observed inhibition zones only by the spot-on-a-lawn method against most of the yeasts tested, an event that was not evidenced for the other two diffusion techniques (Disk and well) which did not show any activity Table $2 .{ }^{30}$ reported activity on the methanolic extract of E. cirrhatum evaluated at $100 \mathrm{mg} / \mathrm{mL}$ against Candida albicans and

Table I Results of the antibacterial activity of the ethanol and dichloromethane extracts of Everniastrum cf. vexans, Parmotrema blanchetianum, Parmotrema reticulatum and Peltigera laciniata

\begin{tabular}{|c|c|c|c|c|c|c|c|}
\hline \multirow{3}{*}{ Method } & \multicolumn{7}{|c|}{ Inhibition zone of ETOH extracts (Mm) } \\
\hline & \multirow{2}{*}{ Bacteria } & E.v & \multirow{2}{*}{$\begin{array}{l}\text { P. } \mathbf{b} \\
\bar{X} \pm S . D\end{array}$} & P. $r$ & \multicolumn{2}{|l|}{ P. I } & \multirow{2}{*}{$\begin{array}{l}\text { Chloramphen } \\
\bar{X} \pm \text { S.D }\end{array}$} \\
\hline & & $\bar{X} \pm$ S.D & & $\bar{X} \pm S . D$ & $\bar{X} \pm \mathbf{S} . \mathrm{D}$ & & \\
\hline \multirow{7}{*}{ Spot-on-a-law } & S. aureus & - & - & $5.6 \pm 1 . .5^{*}$ & - & \multirow{7}{*}{$100 \mathrm{mg} / \mathrm{ml}$} & $25.0 \pm 0.8$ \\
\hline & L. monocytogenes & - & - & - & - & & - \\
\hline & P. vulgaris & $7.3 \pm 0.5^{*}$ & $7.0 \pm 2.0^{*}$ & $6.0 \pm 0.0 *$ & $9.3 \pm 0.5^{*}$ & & $22.0 \pm 0.5$ \\
\hline & E. coli & - & - & - & - & & - \\
\hline & P. aeruginosa & - & - & - & - & & $25.0 \pm 0.0$ \\
\hline & K. pneumoniae & - & - & - & - & & $13.0 \pm 1.5$ \\
\hline & S. aureus & - & - & $-*$ & - & & $25.0 \pm 0.8$ \\
\hline \multirow{4}{*}{ Disc diffusion } & L. monocytogenes & - & - & - & - & \multirow{4}{*}{$100 \mathrm{mg} / \mathrm{ml}$} & - \\
\hline & P. vulgaris & $-*$ & $-*$ & $-*$ & $-*$ & & $22.0 \pm 0.5$ \\
\hline & E. coli & - & - & - & - & & - \\
\hline & P. aeruginosa & - & - & - & - & & $25.0 \pm 0.0$ \\
\hline \multirow{8}{*}{ Well diffusion } & K. pneumoniae & - & - & - & - & \multirow{7}{*}{$100 \mathrm{mg} / \mathrm{ml}$} & $13.0 \pm 1.5$ \\
\hline & S. aureus & - & - & $7.00 \pm 00^{*}$ & - & & $25.0 \pm 0.8$ \\
\hline & L. monocytogenes & - & - & - & - & & - \\
\hline & P. vulgaris & $8.0 \pm 0.0^{*}$ & $6.3 \pm 1.5 *$ & $8.5 \pm 2.0 *$ & $7.0 \pm 1.0 *$ & & $22.0 \pm 0.5$ \\
\hline & E. coli & - & - & - & - & & - \\
\hline & P. aeruginosa & - & - & - & - & & $25.0 \pm 0.0$ \\
\hline & K. pneumoniae & - & - & - & - & & $13.0 \pm 1.5$ \\
\hline & \multicolumn{5}{|c|}{ Inhibition zone of DCM extracts (mm) } & & \\
\hline \multirow{6}{*}{ Spot-on-a-law } & S. aureus & - & - & - & - & \multirow{6}{*}{$100 \mathrm{mg} / \mathrm{ml}$} & $25.0 \pm 0.8$ \\
\hline & L. monocytogenes & - & - & - & - & & - \\
\hline & P. vulgaris & $20.3 \pm 0.5$ & $6.0 \pm 0.0$ & $7.0 \pm 2.0$ & $11.3 \pm 0.5$ & & $22.0 \pm 0.5$ \\
\hline & E. coli & - & - & - & - & & - \\
\hline & P. aeruginosa & - & - & - & - & & $25.0 \pm 0.0$ \\
\hline & K. pneumoniae & - & - & - & - & & $13.0 \pm 1.5$ \\
\hline \multirow{6}{*}{ Disc diffusion } & & - & - & - & - & \multirow{6}{*}{$100 \mathrm{mg} / \mathrm{ml}$} & $25.0 \pm 0.8$ \\
\hline & L. monocytogenes & - & - & - & - & & - \\
\hline & P. vulgaris & -* & -*$^{*}$ & $-*$ & -* & & $22.0 \pm 0.5$ \\
\hline & E. coli & - & - & - & - & & - \\
\hline & P. aeruginosa & - & - & - & - & & $25.0 \pm 0.0$ \\
\hline & K. pneumoniae & - & - & - & - & & $13.0 \pm 1.5$ \\
\hline
\end{tabular}

Cryptococcus neoformans, presenting inhibition zones of 2.5 and $2.6 \mathrm{~mm}$ respectively. This study E.cf vexans, was positive against the same yeasts used by and at the same concentration, obtaining halos with a larger diameter ( 8.3 and $7.3 \mathrm{~mm}$ respectively), but by spoton-a-lawn method, the techniques disc diffusion and diffusion in well did not yield positive results Figure 4. 


\begin{tabular}{|c|c|c|c|c|c|c|c|}
\hline \multirow[t]{2}{*}{ Method } & \multicolumn{7}{|c|}{ Inhibition zone of ETOH extracts ( $\mathrm{Mm})$} \\
\hline & S. aureus & - & - & - & - & & $25.0 \pm 0.8$ \\
\hline & L. monocytogenes & - & - & - & - & & - \\
\hline & P. vulgaris & $18.3 \pm 1.5$ & $6.0 \pm 0.0$ & $7.5 \pm 0.5$ & $8.3 \pm 0.5$ & & $22.0 \pm 0.5$ \\
\hline \multirow[t]{4}{*}{ Well diffusion } & & & & & & $100 \mathrm{mg} / \mathrm{ml}$ & \\
\hline & E. coli & - & - & - & - & & - \\
\hline & P. aeruginosa & - & - & - & - & & $25.0 \pm 0.0$ \\
\hline & K. pneumoniae & - & - & - & - & & $13.0 \pm 1.5$ \\
\hline
\end{tabular}

$\mathrm{EtOH}$, ethanol extracts; DCM, dichloromethane extracts; Sign Sign, without activity; Ev, Everniastrum cf vexans; Pb, Parmotrema blanchetianum; Pr, Parmotrema reticulatum; PI, Peltigera laciniata $* p<0.05$ represents the statistical difference between the three diffusion methods and between the four lichens used

Table 2 Results of the antifungal activity of the ethanol and dichloromethane extracts of Everniastrum cf vexans, Parmotrema blanchetianum, Parmotrema reticulatum and Peltigera laciniata

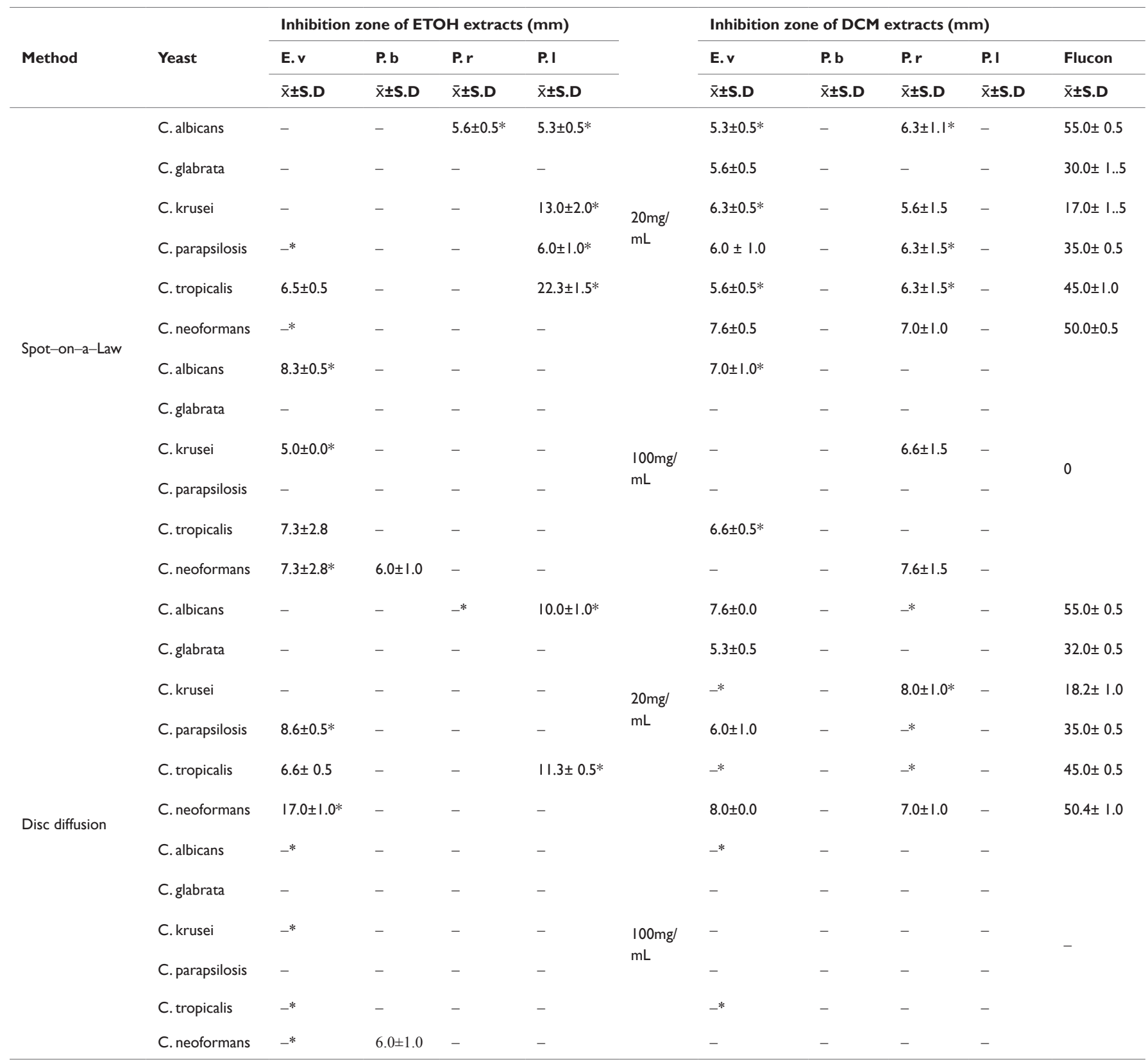

Citation: Plaza CM, Salazar CPD, Plaza RE, et al. In vitro analysis of antibacterial and antifungal potential of lichen species of Everniastrum cf vexans, Parmotrema blanquetianum, Parmotrema reticulatum and Peltigera laciniata. MOJ Drug Des Develop Ther. 20I8;2(3):I25-I34. 


\begin{tabular}{|c|c|c|c|c|c|c|c|c|c|c|c|}
\hline \multirow[t]{6}{*}{ Method } & \multirow{2}{*}{$\begin{array}{l}\text { Yeast } \\
\text { C. albicans }\end{array}$} & \multicolumn{5}{|c|}{ Inhibition zone of ETOH extracts (mm) } & \multicolumn{5}{|c|}{ Inhibition zone of DCM extracts $(\mathrm{mm})$} \\
\hline & & - & - & $-*$ & $10.0 \pm 1.0$ & \multirow{6}{*}{$\begin{array}{l}20 \mathrm{mg} / \\
\mathrm{mL}\end{array}$} & $7.3 \pm 0.5$ & - & $-*$ & - & $50.3 \pm 0.5$ \\
\hline & C. glabrata & - & - & - & - & & $5.3 \pm 0.5$ & - & - & - & $32.0 \pm 1.5$ \\
\hline & C. krusei & - & - & - & - & & $-*$ & - & $6.0 \pm 1.0$ & - & $18.0 \pm 0.5$ \\
\hline & C. parapsilosis & $8.0 \pm 1.0 *$ & - & - & - & & $13.0 \pm 1.5^{*}$ & - & $-*$ & - & $35.3 \pm 0.5$ \\
\hline & C. tropicalis & $7.0 \pm 0.0$ & - & - & $7.0 \pm 1.0 *$ & & _* & - & -* & - & $45.0 \pm 1.5$ \\
\hline \multirow{6}{*}{ Well diffusion } & C. neoformans & $13.6 \pm 1.5^{*}$ & - & - & - & & $8.3 \pm 0.5$ & - & $7.0 \pm 1.0$ & - & $50.0 \pm 0.5$ \\
\hline & C. albicans & $-*$ & - & - & - & \multirow{5}{*}{$\begin{array}{l}100 \mathrm{mg} / \\
\mathrm{mL}\end{array}$} & $-*$ & - & - & - & \multirow{5}{*}{-} \\
\hline & C. glabrata & - & - & - & - & & - & - & - & - & \\
\hline & C. krusei & $-^{*}$ & - & - & - & & - & - & - & - & \\
\hline & C. parapsilosis & - & - & - & - & & - & - & - & - & \\
\hline & C. neoformans & -* & -* & - & - & & - & - & - & - & \\
\hline
\end{tabular}

EtOH, ethanol extracts; DCM, dichloromethane extracts, Sign: without activity. Flucon. Fluconazole. Ev, Everniastrum cf vexans; Pb, Parmotrema blanchetianum; Pr, Parmotrema reticulatum; PI, Peltigera laciniata $* p<0.05$ represents the statistical difference between the three diffusion methods in each extract
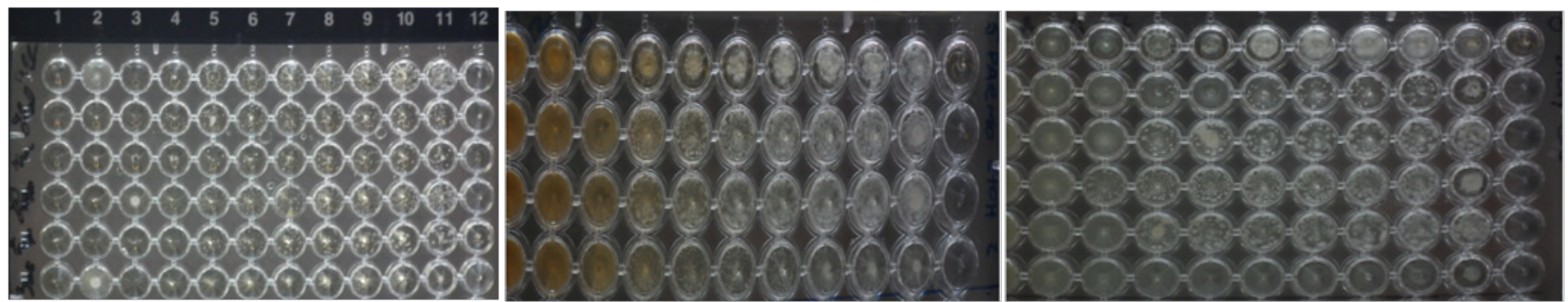

Figure 3 Minimum Inhibitory Concentrations (MIC).
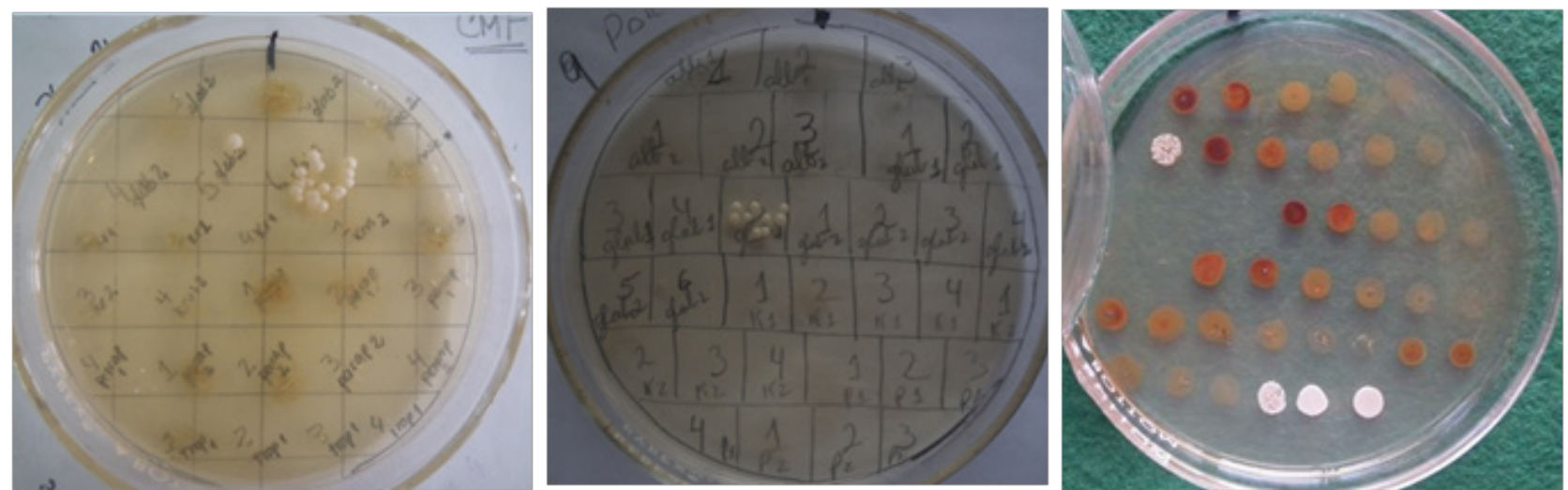

Figure 4 Minimum Bactericidal Concentrations (MBC).

On the other hand, the ethanolic extract of Parmotrema blanchetianum only inhibited the growth of Cryptococcus neoformans at the highest concentration studied, coinciding with this effect through two techniques. The results of the ethanolic extract of Parmotrema reticulatum, showed activity at $20 \mathrm{mg} / \mathrm{mL}$ only against Candida albicans Table 2. In contrast to these results, reported inhibition of yeast growth Candida albicans and Cryptococcus var. diffluens, in acetone and methanolic extracts of Parmotrema nilgherrense and $\mathrm{P}$. sancti-angelii, in a concentration of $10 \mu \mathrm{g} / \mathrm{mL}$ obtaining halos of 7 and $8 \mathrm{~mm}$ respectively Hoda \& Vijayaraghavan, ${ }^{2}$ obtained inhibition growth of Candida albicans and Cryptococcus neoformans with the hexane extract of $P$. reticulatum at $100 \mathrm{mg} / \mathrm{mL}$, reporting halos of 10.4 and $9 \mathrm{~mm}$ respectively. In the case of ethanolic extract of Peltigera laciniata was positive against some yeast at $20 \mathrm{mg} / \mathrm{mL}$, confirm some results with the others two techniques. Few reports of antifungal activity have been found in species of the genera Peltigera. ${ }^{31}$ reported higher activity in polar extracts (petroleum ether, chloroform and acetone) than in polar extracts (ethanol, methanol, water) of Peltigera aphthosa, against Candida albicans in concentrations of 3 and $11 \mathrm{mg}$ / $\mathrm{mL}$. Our study did not coincide with the results given here for the extracts of Peltigera laciniata. The dichloromethane extracts of Everniastrum cf. vexans and Parmotrema reticulatum were actives against all yeast monitors by spot-on-a-lawn method at the lowest tested concentration, corroborating certain positive results with some 
variations by the other two diffusion techniques Table $2 .{ }^{32}$ found activity in dichloromethane extracts of Parmotrema praesorediosum against Candida albicans at $50 \mathrm{mg} / \mathrm{mL}$, obtaining an inhibition zone of $14.1 \mathrm{~mm}$ diameter by only a technique. This indicates that dichloromethane extract of $\mathrm{P}$. reticulatum has antifungal efficacy. Opposite case were presented in the dichloromethane extracts of Parmotrema blanquetianum and Peltigera laciniata, they did not report any inhibitory effect against any yeast tested at any concentration and by any of the techniques used Table 2 . The fluconazole showed inhibition against all tested yeasts pathogens by the three methods used. Also, showed uniformity in the inhibition zones Table 2. The results of our study suggest that the distinct behavior of the species and extracts depends clearly of the different levels of solubility in each extract to capture the active substances in each species. Although the cell wall of fungi is in fact poorly permeable and consists of polysaccharides such as hitchin and glucan. ${ }^{33}$ The intensity of the antimicrobial effect will depend on several factors, including the species of lichen evaluated and therefore the quantity and type of constituents present in each species, besides to the concentration tested and sensitivity of the microorganism used. ${ }^{23}$ Observing the results obtained in this study with the three diffusion methods used, it was noted differences between them despite having the same principal, which is the diffusion of a sample on the medium. These differences could be explained by the diffusion variations of the lichen extract from the surface medium as of a drop or a filter paper until a hole in the surface, as well as the amount of sample used. This generates different results according to diffusion method used. However, the results obtained using spoton-a-lawn and well diffusion methods were reproducible. Analysis of Variance (ANOVA) revealed that there were significant differences among the tree techniques tested, which proved the effectiveness of the methods significantly. In general, the results given in this study for the antibacterial activity were particularly expected; because it was estimated obtain inhibition of growth in most of the bacteria used in all lichen species. This could be influenced by the difficulty of extracts to diffuse into the medium because of its high concentration and low amount $(5 \mu \mathrm{L})$.

\section{Minimum inhibitory concentration in bacterias}

The MIC of the ethanol extracts of the four lichens studied, of gram positive and gram negative bacterias, oscillated in a concentration range between $2.98 \pm 0.0 \mathrm{mg} / \mathrm{mL}$ for Everniastrum vexans and $23.8 \pm 0.0 \mathrm{mg} / \mathrm{mL}$ for Peltigera laciniata Table 3. All the lichen species studied only were actives against Proteus vulgaris except Parmotrema reticulatum that also showed effect against Staphylococcus aureus, results that were obtained from of the diffusion techniques. In a similar way, the results of the MIC of the dichloromethane extracts of all lichens studied only were actives against Proteus vulgaris. The MIC value lowest was given by Parmotrema reticulatum $(1.11 \pm 0.5 \mathrm{mg} / \mathrm{mL})$, followed by Everniastrum cf. vexans $(1.9 \pm 0.8 \mathrm{mg} /$ $\mathrm{mL}$ ) and finally Parmotrema blanquetianum and Peltigera laciniata with $11.9 \pm 0.0 \mathrm{mg} / \mathrm{mL}$ for both Table 3 .

Table 3 MIC and MBC of ethanol and dichloromethane extracts of the four lichen species studied against all the bacteria pathogens used in the study

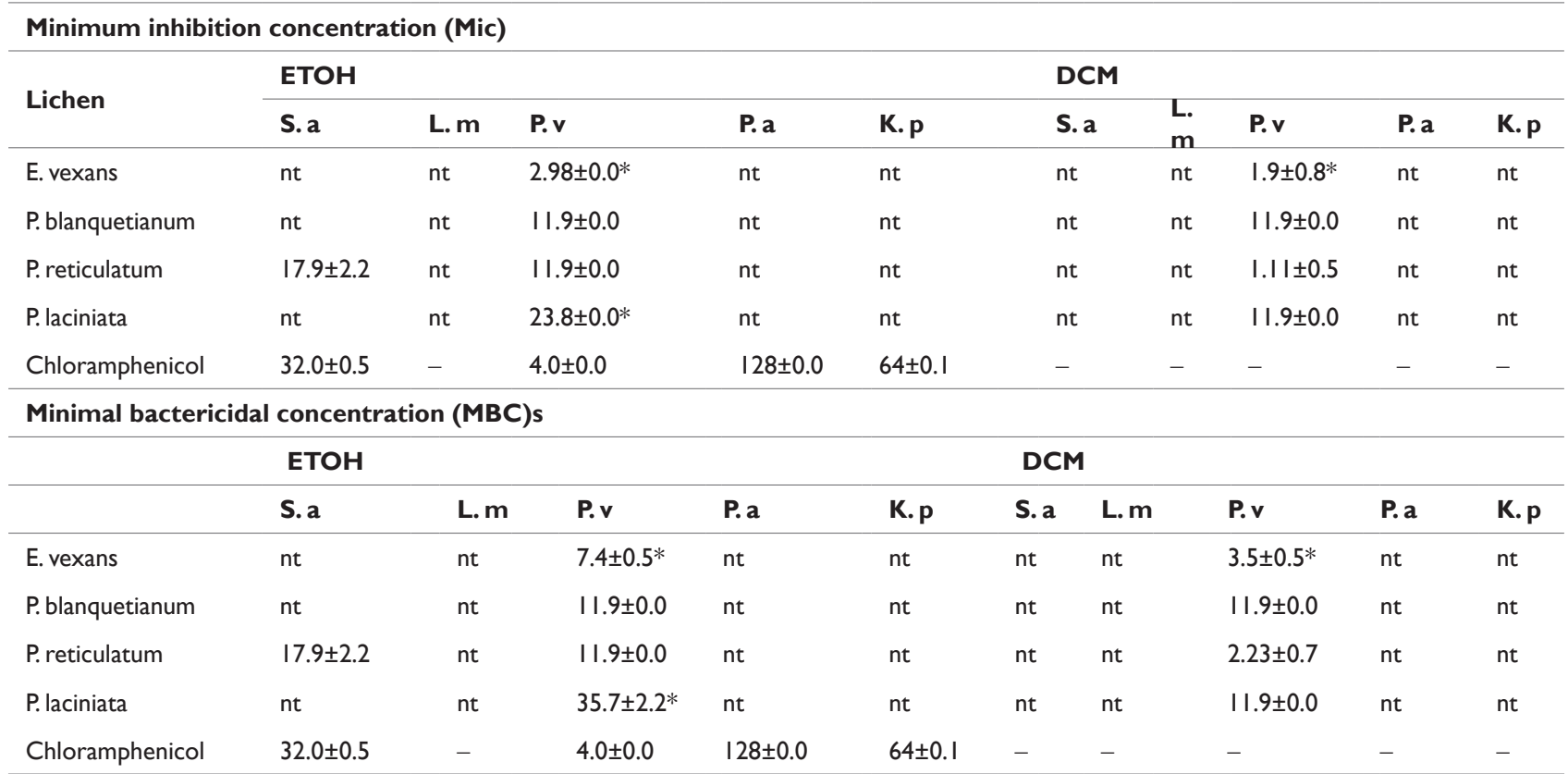

Values are means $\pm S D$ (in $\mathrm{mg} / \mathrm{ml}$ ) of two replicates. ETOH, ethanol extracts; DCM, dichloromethane extracts; Sa, Staphylococcus aureus; Lm, Listeria monocytogenes; Pv, Proteus vulgaris; Pa, Pseudomonas auruginosa; Kp, Klebsiella pneumonia. Positive control expressed in $\mu \mathrm{gg} / \mathrm{mL}$. $* p<0.05$ represents the statistical difference between the MIC and MBC of each extract

\section{Minimum bactericidal concentration}

The MBC of the ethanolic extracts varied between $7.4 \pm 0.5 \mathrm{mg} / \mathrm{mL}$ for Everniastrum vexans and $35.7 \pm 2.2 \mathrm{mg} / \mathrm{mL}$ for Peltigera laciniata. The MBC of the dichloromethane extracts were between $2.23 \pm 0.7 \mathrm{mg} /$ $\mathrm{mL}$ for Parmotrema reticulatum and $11.9 \pm 0.0 \mathrm{mg} / \mathrm{mL}$ for the others species Table 3. According to the results the ethanol extracts of the species Parmotrema blanquetianum and P. reticulatum behaved as bacteriostatic and bactericidal, because showed the same value in MIC and MBC. In the same way, the dichloromethane extracts of the species P. blanquetianum and Peltigera laciniata presented the same values of concentration Table 3. The MIC and MBC of standard chloramphenicol were the same, acting like bacteriostatic and bactericidal. 


\section{Minimum inhibitory concentration in yeast}

The MIC of the ethanolic extracts of the lichens studied against the tested yeasts, oscillated in a concentration range between $0.9 \pm 0.8$ and $23.8 \pm 0.0 \mathrm{mg} / \mathrm{mL}$ Table 4 . The best antifungal activity was shown by the ethanolic extract of Everniastrum $\mathrm{cf}$. vexans, which inhibited the growth of all yeasts at relatively low concentrations $(0.9 \pm 0.8$ and $4.7 \pm 2.2 \mathrm{mg} / \mathrm{mL})$, followed by Parmotrema blanchetianum $(0.7 \pm 0.3-$ $23.8 \pm 0.0 \mathrm{mg} / \mathrm{mL})>$ Peltigera laciniata $\quad(7.4 \pm 0.3-17.9 \pm 2.2 \mathrm{mg} / \mathrm{mL})$ and the highest MFC were reported for Parmotrema reticulatum
$(11.9 \pm 0.0-17.9 \pm 2.2 \mathrm{mg} / \mathrm{mL})$ Table 4. Otherwise, the MIC of the dichloromethane extracts of the four lichens evaluated, reported concentration ranges between $0.002 \pm 0.0$ and $23.8 \pm 0.0 \mathrm{mg} / \mathrm{mL}$. Equally, the best antifungal activity was shown by Everniastrum $\mathrm{cf}$. vexans with lower MICs against all yeast monitors $(0.002-0.6 \mathrm{mg} /$ $\mathrm{mL}$ ) and with Parmotrema reticulatum was obtained concentrations between $0.7 \pm 0.3$ and $7.4 \pm 0.1 \mathrm{mg} / \mathrm{mL}$ Table 4 . The others two lichens Parmotrema blanquetianum and Peltigera laciniata weren't tested for not having any activity in the diffusion techniques Table 2 .

Table 4 MIC and MFC of ethanol and dichloromethane extracts of the four lichen species studied against all the yeast pathogens used in the study

Minimum inhibition concentration (Mic)

\begin{tabular}{|c|c|c|c|c|c|c|c|c|c|c|c|c|}
\hline \multirow{2}{*}{ Lichen } & \multicolumn{6}{|l|}{ ЕтОН } & \multicolumn{6}{|l|}{ DCM } \\
\hline & C. $a$ & C. $g$ & C. $k$ & C. $p$ & C. $\mathrm{t}$ & C. $n$ & C. $a$ & C. $g$ & C. $k$ & C. $p$ & C. $\mathrm{t}$ & C. $n$ \\
\hline $\begin{array}{l}\text { Everniastrum } \\
\text { vexans }\end{array}$ & $4.7 \pm 2.2$ & $0.9 \pm 0.8$ & $1.9 \pm 1.8$ & $4.7 \pm 2.2$ & $4.7 \pm 2.2$ & $3.7 \pm 2.2$ & $0.002 \pm 0.0$ & $0.006 \pm 0.0$ & $0.012 \pm$ & $0.6 \pm$ & $0.6 \pm 0.3$ & $0.02 \pm$ \\
\hline $\begin{array}{l}\text { Parmotrema } \\
\text { blanquetianum }\end{array}$ & $23.8 \pm 0.0$ & $1.5 \pm 0.0$ & $2.2 \pm 0.7$ & $7.4 \pm 3.3$ & $2.2 \pm 0.7$ & $0.7 \pm 0.3$ & nt & nt & nt & $\mathrm{nt}$ & $\mathrm{nt}$ & $\mathrm{nt}$ \\
\hline $\begin{array}{l}\text { Parmotrema } \\
\text { reticulatum }\end{array}$ & $17.9 \pm 2.2$ & $11.9 \pm 0.0$ & $11.9 \pm 0.0$ & $11.9 \pm 0.0$ & $11.9 \pm 0.0$ & $11.9 \pm 0.0$ & $2.9 \pm 0.5$ & $1.5 \pm 0.0$ & $2.2 \pm 0.5$ & $7.4 \pm 0.1$ & $2.2 \pm 0.5$ & $0.7 \pm 0.3$ \\
\hline $\begin{array}{l}\text { Peltigera } \\
\text { laciniata }\end{array}$ & $17.9 \pm 2.2$ & $7.4 \pm 0.3$ & $11.9 \pm 0.0$ & $11.9 \pm 0.0$ & $14.8 \pm 1.6$ & $11.9 \pm 0.0$ & nt & nt & nt & $\mathrm{nt}$ & $\mathrm{nt}$ & $\mathrm{nt}$ \\
\hline Fluconazol & $8 \pm 1.5$ & $8 \pm 0.5$ & $16 \pm 1.0$ & $4 \pm 0.5$ & $4 \pm 0.0$ & $4 \pm 0.1$ & & & & & & \\
\hline
\end{tabular}

Minimal fungicidal concentration (MFC)

\begin{tabular}{|c|c|c|c|c|c|c|c|c|c|c|c|c|}
\hline & C. a & C. $g$ & C. $k$ & C. p & C. $t$ & C. $n$ & C. $a$ & C. $g$ & C. $k$ & C.p & C. $\mathrm{t}$ & C. $n$ \\
\hline Everniastrum vexans & $8.9 \pm 2.2$ & $1.7 \pm 1.8$ & $3.7 \pm 0.5$ & $11.9 \pm 0.0$ & $4.7 \pm 2.2$ & $3.7 \pm 3.1$ & $0.02 \pm 0.0$ & $0.04 \pm 0.0$ & $0.04 \pm 0.0$ & $0.9 \pm 0.7$ & $0.9 \pm 0.7$ & $\begin{array}{l}0.02 \\
\pm 0.0\end{array}$ \\
\hline $\begin{array}{l}\text { Parmotrema } \\
\text { blanquetianum }\end{array}$ & $29.0 \pm 0.7$ & $4.7 \pm 2.2$ & $11.9 \pm 0.0$ & $11.9 \pm 0.0$ & $8.9 \pm 2.2$ & $2.9 \pm 0.0$ & nt & nt & nt & $\mathrm{nt}$ & $\mathrm{nt}$ & $\mathrm{nt}$ \\
\hline $\begin{array}{l}\text { Parmotrema } \\
\text { reticulatum }\end{array}$ & $17.9 \pm 2.2$ & $11.9 \pm 0.0$ & $23.8 \pm 0.0$ & $23.8 \pm 0.0$ & $47.6 \pm 0.0$ & $17.9 \pm 2.2$ & $11.9 \pm 0.0$ & $1.5 \pm 0.0$ & $8.9 \pm 2.2$ & $11.9 \pm 0.0$ & $5.9 \pm 0.0$ & $\begin{array}{l}0.7 \\
\pm 0.0\end{array}$ \\
\hline Peltigera laciniata & $23.8 \pm 0.0$ & $11.9 \pm 0.0$ & $11.9 \pm 0.0$ & $11.9 \pm 0.0$ & $17.8 \pm 2.2$ & $23 \pm 0.0$ & $\mathrm{nt}$ & nt & $\mathrm{nt}$ & $\mathrm{nt}$ & $\mathrm{nt}$ & $\mathrm{nt}$ \\
\hline Fluconazol & $16 \pm 1.5$ & $16 \pm 0.5$ & $32 \pm 0.1$ & $8 \pm 0.5$ & $8 \pm 0.0$ & $8 \pm 0.1$ & & & & & & \\
\hline
\end{tabular}

Values are means $\pm \mathrm{SD}$ (in $\mathrm{mg} / \mathrm{ml}$ ) of two replicates. EtOH, ethanol extracts; DCM, dichloromethane extracts; $\mathrm{Ca}$, Candida albicans; $\mathrm{Cg}$, Candida glabrata; $\mathrm{Ck}$, Candida krusei; $C_{t}$, Candida tropicalis; $\mathrm{Cp}$, Candida parapsilosis; $\mathrm{Cn}, \mathrm{Cryptococcus} \mathrm{neoformans.} \mathrm{The} \mathrm{antifungal} \mathrm{as} \mathrm{positive} \mathrm{control} \mathrm{is} \mathrm{expressed} \mathrm{in} \mu \mathrm{g} / \mathrm{mL}$

\section{Minimum fungicidal concentration}

The results of the MFC showed that the lowest concentrations against the yeast strains tested were reported for the ethanolic extract of Everniastrum cf. vexans $(1.7 \pm 1.8-11.9 \pm 0.0 \mathrm{mg} / \mathrm{mL})$ followed of Parmotrema blanchetianum $(2.9 \pm 0.0-29.0 \pm 0.7 \mathrm{mg} / \mathrm{mL})>$ Peltigera laciniata $(11.9 \pm 0.0-23.8 \pm 0.0 \mathrm{mg} / \mathrm{mL})$ and the highest $\mathrm{MFC}$ were reported for Parmotrema reticulatum $(11.9 \pm 0.0-47.6 \pm 0.0 \mathrm{mg} /$ $\mathrm{mL})$. The MFC of the dichloromethane extracts were: $E$. cf. vexans $(0.02 \pm 0.0-0.9 \pm 0.7 \mathrm{mg} / \mathrm{mL})$ P. reticulatum $(0.7 \pm 0.0-7.4 \pm 0.1 \mathrm{mg} / \mathrm{mL})$. The MFC of fluconazole as positive control were double the MIC Table 4. The ethanol extracts of Everniastrum cf. vexans, Parmotrema reticulatum and Peltigera laciniata reported the same inhibitory concentrations and fungicidal with some yeast, resulting in some case like fungicides. Previous studies have shown equivalent antimicrobial activity in analog lichens. Hoda \& Vijayaraghavan ${ }^{2}$ reported the MIC of hexane extract of Parmotrema perlatum with 9 and $10.4 \mathrm{mg} / \mathrm{mL}$ against Candida albicans and Cryptococcus neoformans respectively. Our study showed concentrations between 17.9 and $11.9 \mathrm{mg} / \mathrm{mL}$ close at the reported by Hoda \& Vijayaraghavan. ${ }^{2}$ However, there are reports those who have nothing of likeness. ${ }^{34}$ determinate the MIC of hexane extract of Parmotrema nilgerensis against Proteus vulgaris obtaining a concentration of $3.125 \times 10^{-5} \mathrm{mg} / \mathrm{mL}$. In this study, we reported a MIC of $11.9 \mathrm{mg} / \mathrm{mL}$ in ethanol extracts and $1.1 \mathrm{mg} / \mathrm{mL}$ in dichlorometane extracts of $P$. blanquetianum and $P$. reticulatum respectively Table 3. Few investigations determine MBC or MFC of the extracts or substances. The similarities and differences in the activity of the extracts of the different lichen species may be a consequence of the chemical diversity of bioactive compounds that interact with the proteins targets of microorganisms, In addition, it could also be attributed by the synergism or antagonisms between different components with antimicrobial activity or their low quantities, probably lower than their MIC, together with the varied solubility of these compounds, the extraction methods, collection season of the samples, the environment where these are developed and the genetic differences between the samples studied. Undoubtedly the activity in the different species depends on the bioactive metabolites present in each lichen, the amount of these and the synergism or activity of the individual components of each extract. ${ }^{34}$ The present study revealed and confirmed the presence of antibacterial and fungicidal substances in the tested extracts of Everniastrum cf vexans, Parmotrema blanquetianun, Parmotrema reticulatum and Peltigera laciniata. According to the literature consulted to date, no reports available on the studies of antimicrobial properties of lichens from Venezuelan Andes, so this study can be considered pioneering for these organisms. 


\section{Conclusion}

It may be concluded from the present study that bioactive compounds from the four lichen species studied, can be employed in the formulation of antimicrobial agents for the treatment of various pathogenic infections. Besides, we can conclude that according the results in this investigation, it is very important to use one or two methodologies to corroborate the inhibitory effect that a compound or extract may have, since according to its chemical nature it can provide different results. Further studies should be done related to isolation, identification, purification and characterization of the compounds responsible for fungicidal activity. Consequently, determination of the therapeutic substances and their spectrum of efficacy which will be a great help in the field of disease management.

\section{Acknowledgments}

Authors are thankful to colleagues from Mycological Laboratory at the Department of Microbiology at Facultad de Farmacia y Bioanálisis-ULA, especially Alexander Moreno and Oduar Salazar, for their support and cooperation on this work.

\section{Conflict of inertest}

Author declares that there is no conflict of interest.

\section{References}

1. Kumar P, Kekuda P, Vinayaka K, et al. Studies on antibacterial, antihelmintic and antioxidant activities of a Macrolichen Parmotrema pseudotinctorum Hale (Parmeliaceae) from Bhadra wildlife sanctuary. International Journal of Pharm Tech Research. 2010;2(2):1207-1214.

2. Hoda S, Vijayaraghavan P. Evaluation of Antimicrobial prospective of Parmotrema perlatum Hexane Extract. International Journal of Pharmaceutical Research and Allied Sciences. 2015;4(2):47-53.

3. Mitrović T, Stamenković S, Cvetković V, et al. Antioxidant, antimicrobial and antiproliferative activities of five lichen species. International Journal of Molecular Sciences. 2011;12(8):5428-5448.

4. Ginto G, Pratap C, Manju S, et al. Antioxidant and Antibacterial Activity of Parmotrema stuppeum (Taylor) Hale. Journal of Biologically Active Products from Nature. 2014;4(6):365-370.

5. Srivastava P, Upreti D, Dhole T, et al. Antimicrobial property of extracts of Indian lichen against human pathogenic bacteria. Interdisciplinary Perspectives on Infectious Diseases. 2013;(6):709348.

6. Esteban I. Líquenes usados en medicina tradicional. Boletín de la Sociedad Micológica de Madrid. 2012;36:163-174.

7. Feuerer T. Checklist of lichens and lichenicolous fungi of Venezuela. USA; 2008.

8. Lücking R, Rivas Plata E, Chaves JL, et al. How many tropical lichens are there... really? Bibliotheca Lichenologica. 2009;100:399-418.

9. Marcano V. Introducción al estudio de los líquenes y su clasificación, Colección Flora Liquénica de los Andes Venezolanos. Ediciones de Fundacite Mérida. 1994:338.

10. Hale ME. A monograph of Parmelia subgenus Amphigymnia. United States National Herbarium. 1965;36(5):193-358.

11. López F. Censo de macrolíquenes de los andes venezolanos (primera parte). Facultad de Farmacia. Spain; 1978. 209 p.

12. Yánez A. Los géneros Hypotrachynay Everniastrum (Parmeliaceae, Ascomycota liquenizados) enlas provinciasde Carchie Imbabura dela región andina del Ecuador. Tesis de Maestría. 2009.
13. Jayalal U, Pradeep K, Divakar P, et al. The lichen genus Parmotrema in South Korea. Mycobiology. 2013;41(1):25-36.

14. Vera E, Salvucci E, Sesma F, et al. Different strategies for purification of antimicrobial peptides from Lactic Acid Bacteria (LAB). Communicating Current Research and Educational. Topics and Trends in Applied Microbiology. 2007;557-568.

15. Vizcaya M, Pérez C, Rojas J, et al. Composición químicay evaluación de la actividad antifúngica del aceite esencial de corteza de Vismia baccifera vardealbata. Revista de la Sociedad Venezolana de Microbiología. 2014;34:86-90.

16. KaragözA, Doğruöz N,Zeybek Z, et al. Antibacterial activity of some lichen extracts. Journal of Medicinal Plants Research. 2009;3(12):1034-1039.

17. Salazar D, Hernández Y, Palma S, et al. Actividad antimicrobiana dedoce fármacos frente a cepas de Pseudomonas aeruginosa de origen clínico. Bioquimia. 2001;26(4):79-84.

18. NCCLS (National Commitee for Clinical Laboratory Standards) Reference method for broth dilution antifungal susceptibility testing of yeasts; approved standard-Second edition (M27-A2). USA; 2002. 29 p.

19. Verma N, Behera B, Parizadeh H, et al. Bactericidal activity of some lichen secondary compounds of Cladonia ochrochlora, Parmotrema nilgherrensis \& Parmotrema sancti-angelii. International Journal of Drug Development \& Research. 2011;3(3):222-232.

20. Goodman-Gilman A, Rall T, Nies A, et al. Agentes antimicrobianos Consideraciones generales en: Las bases farmacológicas de la terapéutica, Ecuador; 1991.

21. Espinel-Ingroff A, Chaturvedi V, Fothergill A, et al. Optimal testing conditions for determining MICs and minimum fungicidal concentrations of new and established antifungal agents for uncommon molds: NCCLS collaborative study. Journal of Clinical Microbiology. 2002;40(10):37763781 .

22. Baral B, Maharjan B. Assessment of antimicrobial and phytochemical potentials of high altitudinal Nepalese lichens. Journal of Microbiology, Biotechnology and Food Sciences. 2011;1(2):98-112.

23. Kosanić M, Ranković B. Antioxidant and antimicrobial properties of some lichens and their constituents. Journal of Medicinal Food. $2011 ; 14(12): 1624-1630$

24. Yilmaz M, Türk A, Tay T, et al. The Antimicrobial Activity of Extracts of the Lichen Cladonia foliacea and Its (-)usnic acid, atranorin, and fumarprotocetraric acid constituents. Zeitschrift für Naturforsch. 2004;59(4):249-254.

25. Ribeiro S, Pereira E, Buarque-Guzmão N, et al. Produção de metabólitos bioactivos pelo liquen Cladonia substellata Vainio. Acta Botanica Brasilica. 2006;20(2):265-272.

26. Santiago K, Borricano J, Canal J, et al. Antibacterial activities of fruticose lichens collected from selected sites in Luzon Island, Philippines. Philippine Science Letter. 2010;3(2):18-29.

27. Sharma B, Kalikotay S, Bimala R. Assessment of antimicrobial activity of extracts of few common lichens of Darjeeling Hills. Indian Journal of Fundamental and Applied Life Sciences. 2012;2(1):120-126.

28. Ranković B, Mišić M, Sukdolak S. Antimicrobial activity of extracts of the lichens Cladonia furcata, Parmelia caperata, Parmelia pertusa, Hypogymnia physodes and Umbilicaria polyphylla. Biologia. 2009;64(1):53-58.

29. Swathi D, Suchitha Y, Prashith K, et al. Antimicrobial, anthelmintic and insecticidal activity of a macrolichen Everniastrum cirrhatum (Fr.) Hale. International Journal of Drug Development \& Research. 2010;2(4):780-789. 
30. Kekuda P, Raghavendra H, Swathi D, et al. Antifungal and cytotoxic activity of Everniastrum cirrhatum (Fr.) Hale. Journal of Science. 2012;39(1):76-83.

31. Ingólfsdóttir K, Bloomfield S, Hylands P. In Vitro Evaluation of the Antimicrobial Activity of Lichen Metabolites as Potential Preservatives. Antimicrobial Agents and Chemotherapy. 1985;28(2):289-292.

32. Balaji P, Harihana G. In vitro Antimicrobial Activity of Parmotrema praesorediosum Thallus Extracts. Research Journal of Botany. 2007;2(1):54-59.
33. Kosanić M, Manojlovic N, Jankovic S, et al. Evernia. prunastri and Pseudoevernia. furfuraceae lichens and their major metabolites as antioxidant, antimicrobial and anticancer agents. Food and Chemical Toxicology. 2013;53:112-118.

34. Stojanović G, Stojanović I, Stankov-Jovanović V, et al. Reducing power and radical scavenging activity of four Parmeliaceae species. Central European Journal of Biology. 2010;5(6):808-813. 